\title{
Stress distribution in prosthetic abutments: a finite element analysis comparison of conical and UCLA abutments
}

\author{
Distribuição de tensão em abutments protéticos: uma comparação por análise de elementos finitos \\ de abutments do tipo cônico e UCLA
}

Distribución de esfuerzos en pilares protésicos: una comparación de análisis de elementos finitos de pilares cónicos y UCLA

Received: 10/06/2021 | Reviewed: 10/14/2021 | Accept: 10/15/2021| Published: 10/18/2021

Cristiano Garcia Araújo

ORCID: https://orcid.org/0000-0003-2468-0373 São Leopoldo Mandic, Brazil

E-mail: cristianocga@hotmail.com

Milton Edson Miranda

ORCID: https://orcid.org/0000-0002-5410-6500 São Leopoldo Mandic, Brazil

E-mail: memiranda@memiranda.com.br

Caroline Dini

ORCID: https://orcid.org/0000-0002-2587-3137

University of Campinas, Brazil

E-mail: carolinidini@gmail.com

Gabrielle Alencar Ferreira Silva

ORCID: https://orcid.org/0000-0001-7663-581X

São Leopoldo Mandic, Brazil

E-mail: gabialencarfs15@gmail.com

Karina Andrea Novaes Olivieri

ORCID: https://orcid.org/0000-0001-8843-8901

São Leopoldo Mandic, Brazil

E-mail: drakarinaolivieri@hotmail.com

\begin{abstract}
The effect of prosthetic abutment type on single-screwed prostheses in posterior mandibular molar rehabilitations is not yet known. Thus, the aim of this study was to evaluate the distribution of stresses in the crowns, prosthetic components, implant and bone in implant-supported restorations with or without a prosthetic abutment, maintaining an equal total height of the implant-crown set. Virtual 3-dimensional (3D) finite element models were constructed, the models were designed to represent a posterior single crown rehabilitation with a screwed retention system and external hexagon implants placed in the lower first molar region. Two rehabilitation methods were designed to simulate a monolithic zirconia crown screwed onto a conical abutment, which was screwed onto an external hexagon implant (M1); and a monolithic zirconia crown screwed directly onto the external hexagon implant using an UCLA abutment (M2). An axial load of $200 \mathrm{~N}$ was simulated and applied axially in the occlusal region of the restoration divided into 5 points. The quantitative and qualitative description of the maximum principal stress for crowns, von Mises stress for screws, conical abutment and implant; and minimal principal stress for cortical and medullary bone were evaluated. M1 presented similar stress distribution for crowns, cortical and medullary bone compared to M2. Conversely, the stress values were considerably higher for crowns screw and implants in the M2 group. In conclusion, single implant-supported rehabilitations of mandibular first molars using external hexagon implants presented better stress distribution on the crown screw and implants for the M1 group compared to M2.
\end{abstract}

Keywords: Finite element analysis; Dental implants; Dental stress analysis.

\section{Resumo}

O efeito do tipo de abutment protético em próteses parafusadas nas reabilitações de molares mandibulares posteriores ainda não é conhecido. Assim, o objetivo deste estudo foi avaliar a distribuição de tensões nas coroas, componentes protéticos, implante e osso em restaurações implanto-suportadas com ou sem pilar protético, mantendo uma altura total igual do conjunto implante-coroa. Modelos virtuais tridimensionais (3D) de elementos finitos foram construídos, os modelos foram projetados para representar uma reabilitação de coroa única posterior com um sistema de retenção parafusado e implantes de hexágono externo colocados na região do primeiro molar inferior. Dois métodos de reabilitação foram projetados para simular uma coroa monolítica de zircônia parafusada em um abutment cônico, que foi parafusado em um implante de hexágono externo (M1); e uma coroa monolítica de zircônia parafusada 
diretamente no implante de hexágono externo usando um abutment UCLA (M2). Uma carga axial de $200 \mathrm{~N}$ foi simulada e aplicada axialmente na região oclusal da restauração dividida em 5 pontos. A descrição quantitativa e qualitativa da tensão principal máxima para coroas, tensão de von Mises para parafusos, pilar cônico e implante; e o estresse principal mínimo para o osso cortical e medular foram avaliados. M1 apresentou distribuição de tensões semelhante para coroas, osso cortical e medular em comparação com M2. Por outro lado, os valores de tensão foram consideravelmente maiores para parafusos de coroas e implantes no grupo M2. Em conclusão, as reabilitações implantossuportadas de primeiros molares inferiores com implantes de hexágono externo apresentaram melhor distribuição de tensões no parafuso coronário e implantes para o grupo M1 em comparação com M2.

Palavras-chave: Análise de elementos finitos; Implantes dentários; Análise de estresse dentário.

\section{Resumen}

Aún no se conoce el efecto del tipo de pilar protésico sobre las prótesis de un solo tornillo en las rehabilitaciones de molares mandibulares posteriores. Así, el objetivo de este estudio fue evaluar la distribución de tensiones en las coronas, componentes protésicos, implante y hueso en restauraciones implantosoportadas con o sin pilar protésico, manteniendo una altura total igual del juego implante-corona. Se construyeron modelos virtuales de elementos finitos tridimensionales (3D), los modelos se diseñaron para representar una rehabilitación posterior de una sola corona con un sistema de retención atornillado e implantes hexagonales externos colocados en la región del primer molar inferior. Se diseñaron dos métodos de rehabilitación para simular una corona monolítica de circonio atornillada a un pilar cónico, que se atornillaba a un implante hexagonal externo (M1); y una corona monolítica de circonio atornillada directamente sobre el implante hexagonal externo mediante un pilar UCLA (M2). Se simuló una carga axial de $200 \mathrm{~N}$ y se aplicó axialmente en la región oclusal de la restauración dividida en 5 puntos. La descripción cuantitativa y cualitativa de la tensión principal máxima para coronas, tensión de von Mises para tornillos, pilar cónico e implante; y se evaluó el estrés principal mínimo para el hueso cortical y medular. M1 presentó una distribución de estrés similar para coronas, hueso cortical y medular en comparación con M2. Por el contrario, los valores de tensión fueron considerablemente más altos para coronas de tornillos e implantes en el grupo M2. En conclusión, las rehabilitaciones soportadas por implantes individuales de los primeros molares mandibulares utilizando implantes de hexágono externo presentaron una mejor distribución de la tensión en el tornillo de la corona y los implantes para el grupo M1 en comparación con M2.

Palabras clave: Análisis de elementos finitos; Implantes dentales; Análisis de estrés dental.

\section{Introduction}

Single implant-supported rehabilitations have emerged as a safe and effective alternative for the treatment of partial edentulous patients (Mezzomo et al., 2014; Wang et al., 2020). This treatment presents high survival rates of $97.2 \%$ after 5 years, despite the great biomechanical challenges of this type of rehabilitation (Jung et al., 2012). Hereby, aiming to improve the biomechanics and the predictability of the single implant-supported restorations, different connection systems, abutment type and materials, surface treatments, length and diameter of abutments and implants have been proposed (Di Fiore et al., 2015; Lima de Andrade et al., 2017).

Within the connection systems, external hexagon implants developed by Bränemark have been the most used system and its retention to the prosthetic abutment occurs through a hexagon-shaped fitting. Several drawbacks are reported for this connection system and it has been suggested that, under high occlusal loads, the connection might allow micro movements, resulting in abutment screw loosening or even fatigue fracture (Dias et al., 2012; Pera et al., 2021).

It also must be considered the types of restorations that can be used with respect to the abutment type. The use of an intermediary component between the implant and prosthetic crown (conical abutment) and also prostheses screwed directly on the implant (UCLA abutment) have been used (Araújo et al., 2018). The first comprises a segmented structure with two screwed joints one at implant-abutment interface and another at abutment-prosthesis interface (Ochiai et al., 2003). For the second, a unique screw is used and screwed directly onto the implant.

Implant failures are still a clinical challenge and can be associated with loading conditions, bio-tribocorrosion phenomena, biological reasons (colonization by bacteria in the internal parts of the implant and peri-implant diseases) or mechanical reasons, and micro-movement of the prosthetic components (Coelho et al., 2009; Dini et al., 2020). Thus, an adequate adjustment of the prosthetic components is necessary. Considering the fact that the implants are completely 
surrounded by bone tissue, and that the interface is not elastic, minimal movement can provide bone resorption and loss of components under load (Jaime et al., 2007). Additionally, higher stress on implants, screws and abutments may also predict failures (Tribst et al., 2021).

With the purpose of simulate and analyse the mechanical behavior of materials the three-dimensional (3D) finite element analysis have been extensively used. Through this in silico analysis, it is possible to simulate complex conditions without risk to patients, evaluate the performance and stress distribution in the supporting tissues with the help of a computational model (Costa et al., 2014). This method allows the individual assessment of the influence of variables on the stress generated to the peri-implant bone and on the possible deformation of the system, which is difficult to be investigated using only clinical or in vitro approaches.

In the literature, the effect of prosthetic abutment type, for single-screwed prostheses in posterior mandibular molar on zirconia crowns, crowns screws, conical abutment, abutment screws, implants, cortical and medullary bone is not yet known. Considering that single implant-supported rehabilitation are not splinted and hence subjected to multidirectional loading that challenges the connection components and restoration structural integrity, it is important to evaluate the predictability of this type of rehabilitation (Estrela, 2018; Pereira et al., 2018). Therefore, the aim of this study was to evaluate the distribution of stresses in the crowns, prosthetic components, implant and bone in implant-supported restorations with or without a prosthetic abutment, maintaining an equal total height of the implant-crown set.

\section{Methodology}

Virtual 3-dimensional (3D) finite element models were constructed by using a modeling software program (Solid Works 2013; Dassault Systèmes Solid Works Corp). The models were designed to represent a posterior single crown rehabilitation with a screwed retention system and external hexagon implants placed in the lower first molar region. Two rehabilitation methods were designed to simulate a monolithic zirconia crown screwed onto a conical abutment, which was screwed onto an external hexagon implant (M1); and a monolithic zirconia crown screwed directly onto the external hexagon implant using an UCLA abutment (M2). The prosthetic abutment used in the M1 was a conical titanium abutment for external hexagon implants, measuring $4.1 \mathrm{~mm}$ in diameter and $4.5 \mathrm{~mm}$ in height, with $2.5 \mathrm{~mm}$ of metallic strap. For the group M2, an anti-rotational UCLA abutment was used and the crown was screwed directly onto the external hexagon implants. The crowns of both groups were modeled to obtain an identical occlusal anatomy, only their heights being different, since the M2 crown was screwed directly onto the implant using the UCLA abutment. Thus, the group M2 presented a greater height to compensate for the height of the conical abutment, thus maintaining an equal total height between the two group models (M1 and M2). A titanium screw was also modelled to be screwed onto the external hexagon implant measuring $3.75 \mathrm{~mm}$ in diameter, $11 \mathrm{~mm}$ in height and $4.1 \mathrm{~mm}$ platform. Another titanium fixation screw was modelled to screw the crown to the prosthetic abutment. Both the implant and the cortical bone block and medullary bone were modelled and used for both M1 and M2 (Figure 1).

After modeling all components separately, they were assembled in the 3D finite element analysis software program, generating two experimental models for the groups M1 (Figure 2A) and M2 (Figure 2B), which were imported to the finite element analysis software (ANSYS Workbench 15.0; Ansys Inc) for mathematical analysis. A $70 \mu \mathrm{m}$ mesh of tetrahedral elements was defined after convergence analysis of 5\% and an axial load of $200 \mathrm{~N}$, consistent with reports found in the literature for the posterior region (Figure 3A) (Lemos et al., 2021; Lee et al., 2021). This load was applied axially in the occlusal region of the restoration divided into 5 points according to a normal occlusion (Figure 3B) (Brune et al., 2019; Bordin et al., 2021). 
Figure 1. 3D modeled geometries. A) Prosthetic components for conical (M1) and UCLA (M2) abutments; B) Modeled cortical and medullary bone.

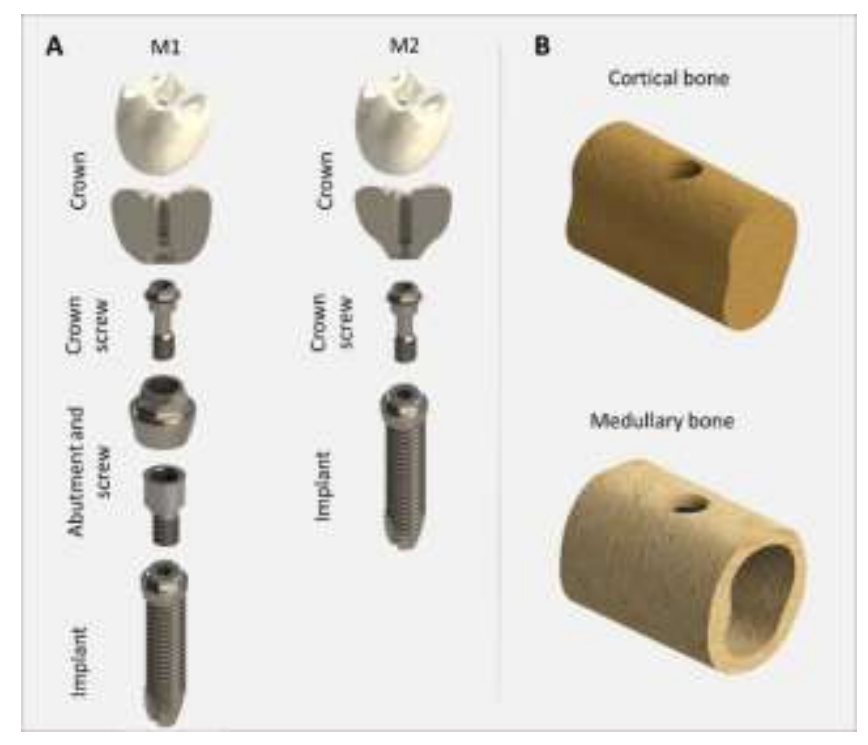

Source: Authors.

Figure 2. Experimental models in isometric and lateral view showing that both sets, despite being different, have the same total height. A) Isometric and lateral view of zirconia crown screwed on conical abutment; B) Isometric and lateral view of zirconia crown screwed directly into the external hexagon implant.

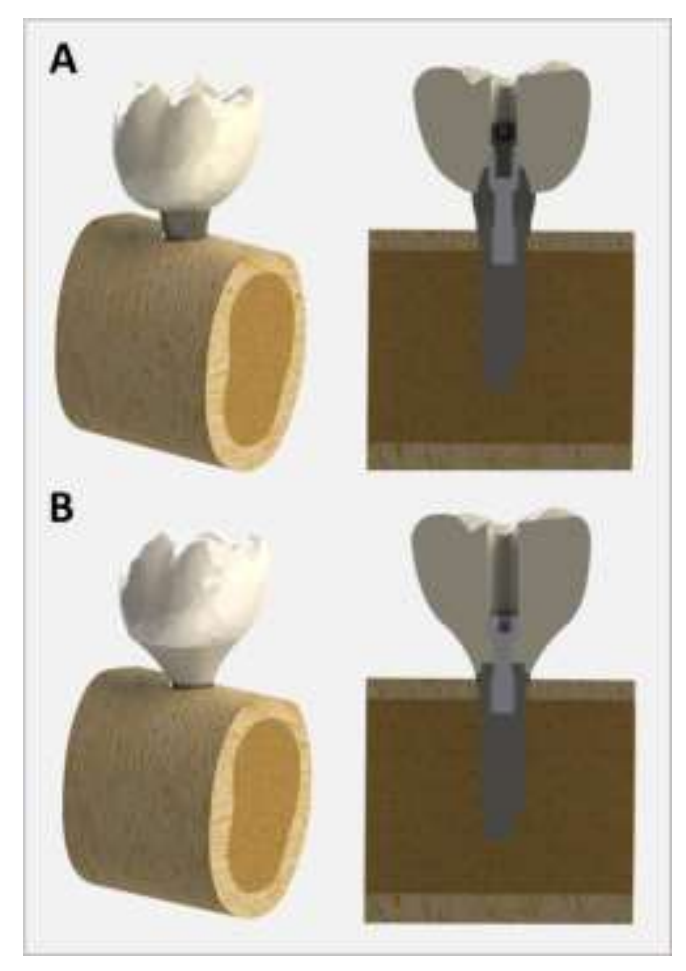

Source: Authors.

The number of nodes and elements used in each model are detailed in Table 1 and the Young modulus and Poisson ratio used for each material are shown in Table 2 (Coelho et al., 2009; Cruz et al., 2010). The data obtained were evaluated 
regarding the quantitative and qualitative description of the maximum principal strain for crowns, von Mises stress for screws, conical abutment and implant; and minimal principal strain for cortical and medullary bone.

Figure 3. A) Model with $70 \mu \mathrm{m}$ tetrahedral elements mesh; B) Direction of axial load application in the occlusal region of the crown.

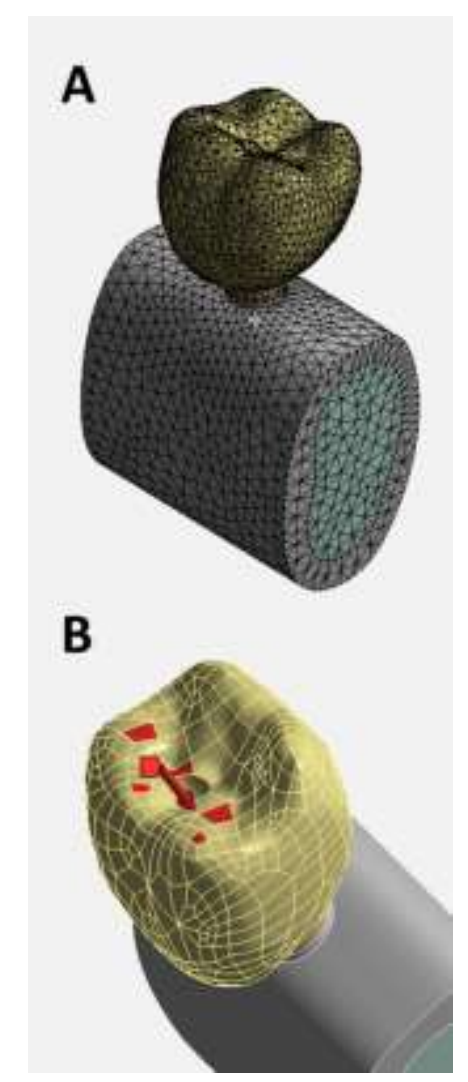

Source: Authors.

Table 1. Number of nodes and elements.

\begin{tabular}{lcr}
\hline Groups & Nodes & Elements \\
\hline M1 & 126.691 & 73.233 \\
\hline M2 & 118.216 & 68.763 \\
\hline \multicolumn{3}{c}{}
\end{tabular}

Table 2. Mechanical properties of materials

\begin{tabular}{lccl}
\hline \multicolumn{1}{c}{ Material } & $\begin{array}{c}\text { Young Modulus } \\
(\mathrm{GPa})\end{array}$ & $\begin{array}{c}\text { Poisson } \\
\text { Ratio }\end{array}$ & \multicolumn{1}{c}{ Reference } \\
\hline Zirconia crown & 205 & 0.22 & Coelho et al., 2009 \\
\hline Titanium material & 110 & 0.33 & Cruz et al., 2009 \\
\hline Cortical bone & 13.60 & 0.26 & Cruz et al., 2009 \\
\hline Medullary bone & 1.36 & 0.31 & Cruz et al., 2009 \\
\hline
\end{tabular}




\section{Results}

Stress distribution on each component have been summarized in Table 3. For zirconia crowns, both groups concentrated tension in the regions close to the load application point. The group M1 presented lower stress (23.878 MPa) than the group M2 (28.211 MPa) (Figure 4A). Considering the different screws geometries used on each group, substantial differences were observed for stress, M1 exhibited 304.91 MPa concentrated between the threads and the screw head, whereas M2 exhibited considerably less tension, reaching values of 171.85 MPa in the screw head region (Figure 4B).

Table 3. Stress distribution (Mpa) for different components.

\begin{tabular}{llcc}
\hline & Components & M1 & M2 \\
\hline Maximum principal stress & Zirconia crown & 23.878 & 28.211 \\
\hline \multirow{2}{*}{ von Mises stress } & Crown screw & 171.85 & 304.91 \\
& Abutment screw & 169.59 & - \\
& Abutment & 38.52 & - \\
& Implant & 31.575 & 130.0 \\
\hline Minimum principal stress & Cortical bone & 44.407 & 42.327 \\
& Medullary bone & 2.6592 & 2.6602 \\
\hline
\end{tabular}

Source: Authors.

Conical abutment and abutment screw are components present only in M1, being therefore absent for comparison with structures present in M2. For abutment screw, the maximum value of von Mises stress was 169.59 MPa located in the internal threads where the crown screw fits (Figure 4C). This result is close to that which also occurred in the crown screw of the same group M1 (171.85 MPa) (Figure 4B). The conical abutment had a maximum von Mises stress of $38.52 \mathrm{MPa}$ located in the upper internal region in contact with the implant fixation (Figure 4C).

The group M2 presented approximately fourfold stress in the implant compared to M1 (Figure 4D). The group M1 present a maximum principal stress of $31.575 \mathrm{MPa}$ in the implant platform, whereas $\mathrm{M} 2$ generated a maximum principal stress of $130 \mathrm{MPa}$. For the cortical bone finite element analysis, there was a similar pattern of compression for M1 (44.407 MPa) and M2 (42.327 MPa). For both groups, this compression occurred in the cortical region in contact with the implant neck, with similar distribution of tension in this region (Figure 4E). For the medullary bone, the results were also similar for both groups (M1 2.65 MPa; and M2 2.66 MPa) (Figure 4F). However, the compression was located in the region of apical contact of the implant with the bone. 
Figure 4. Stress distribution on conical (M1) and UCLA (M2) abutments. A) Stress distribution on crowns of M1 and M2; B) Stress distribution on crowns screw of M1 and M2; C) Stress distribution on abutment screw and abutment of M1; D) Stress distribution on implants of M1 and M2; E) Stress distribution on cortical bone of M1 and M2; F) Stress distribution on medullary bone of M1 and M2.

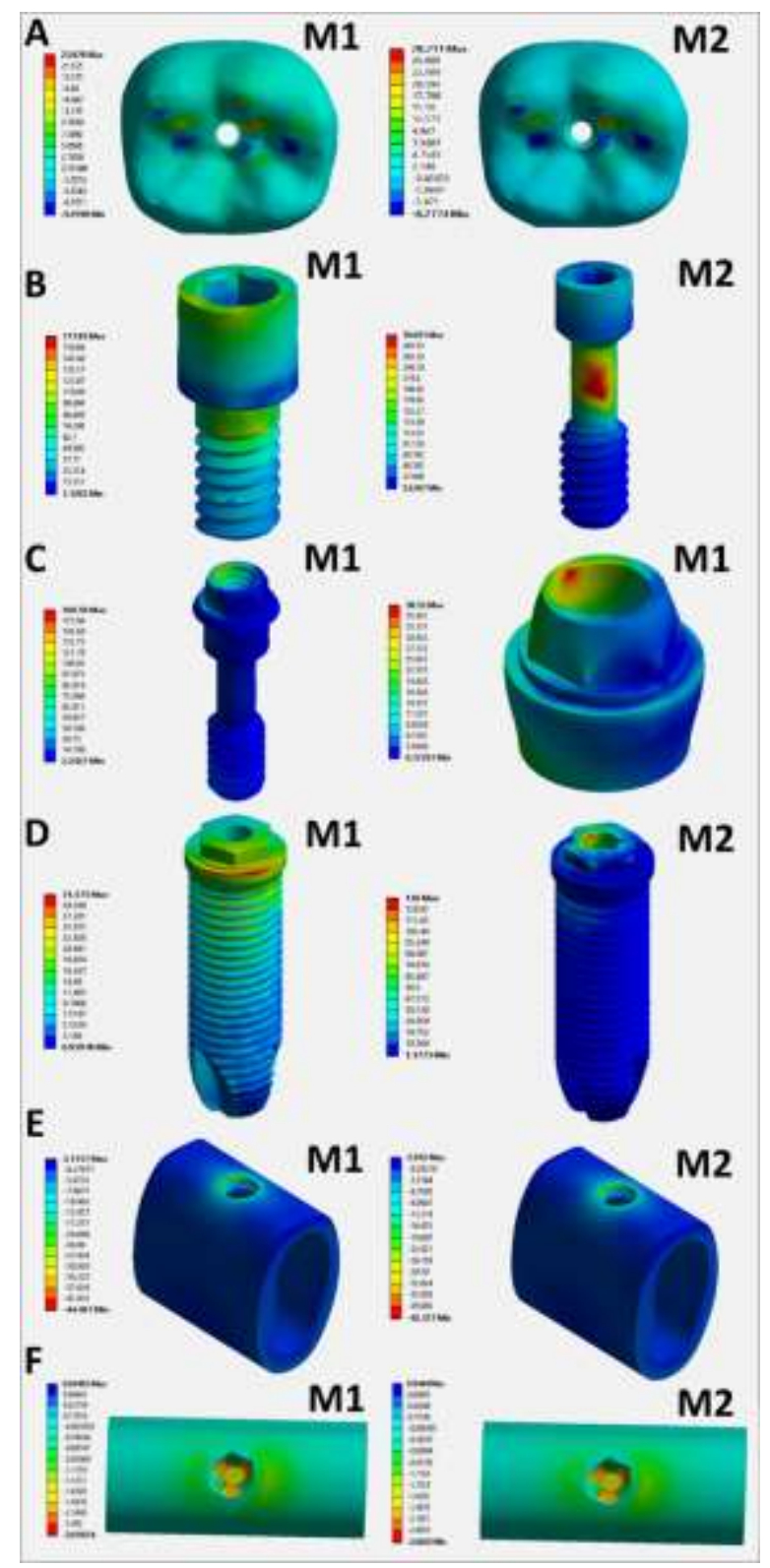

Source: Authors.

\section{Discussion}

The present study revealed that conical compared to UCLA abutments present similar stress distribution for crowns, cortical and medullary bone. Conversely, the stress values were considerably higher for crowns screw and implants in the UCLA (M2) group. Thus, the null hypothesis that different abutment would not result in different stress values in implant components and surrounding bone was rejected.

In general, UCLA abutments induced higher stress in crown screws than that induced by conical abutments. These results may be related to the segmented structure, which is capable to improve biomechanical behavior with the presence of two screwed connections in the conical abutment and increase the total area for stress/strain distribution and dissipation 
through the components (Camargos et al., 2016). These results are consistent with previous studies, which demonstrated that non-segmented abutments generate higher stress compared to segmented abutments (Ochiai et al., 2003; Aalaei et al., 2017).

Therefore, it is important to mention the predictability of each abutment type in case of complications. Considering the UCLA abutments group, crowns are directly screwed onto implants and the higher crown screw stress found in this study may be involved in the development of complications as the treatment failure and increase in the chances of developing periimplant inflammations. For the use of UCLA abutments there are laboratorial steps, such as casting, soldering and porcelain building, or the combination of them, which can result in distortion during prosthesis manufacturing (Das Neves et al., 2014). This is a great disadvantage because the laboratorial steps might cause a misfit. Those disadvantages can also generate biological complications such as increase of load transfer to the bone and hence bone loss, besides peri-implant infections due to bacterial accumulation in the microgap between the abutment and the implant (Dias et al., 2012). Prosthetic complications may also occur as screw loosening and fracture, which may lead to implant loss since for this type of abutment, the screw is screwed directly into the implant and its fracture may make it impossible to use the implant for rehabilitation. For this reason, it is necessary a good laboratory technician to prevent such problems from occurring. In the case of using a conical abutment, a larger contact surface area is present which allows an improved adaptation with compensation of divergences and small distortions, consequently reducing stress concentration (Ochiai et al., 2003).

Concerning the stress distribution on implants, the UCLA abutments group also demonstrated higher values compared to conical abutments. The stress concentration was mainly in the implant neck in contact with the region with the highest stress concentration of the crown screw. Previous studies reported that the design characteristics of the implant-abutment combination with resistance critical points due to the geometry along its length and alteration in cross-sectional area are responsible for higher stress and failure location (Quek et al., 2008). This may explain the higher peak of stress located at the external region of the cervical collar of the implant. In contrast, for the conical abutment group the stress on implants was approximately fourfold lower, besides this lower stress was distributed in the implant surface.

Studies suggest that the use of the prosthetic segmented abutments is directly related to a better distribution of stress (Chun et al., 2005; Aalaei et al., 2017). The implant-abutment connection is believed to play an important role in the treatment outcome. In addition, in cases of unfavorable forces segmented abutments are able to prevent fractures in the crowns screw, which is the weak component that can fracture inside the implant. Furthermore, in cases of non-segmented abutments the crown screws receive directly the occlusal loads, compromising the implant-supported prosthesis.

For zirconia crowns no differences were observed for conical and UCLA abutments. The cortical and medullary bone also did not present differences. These results are in line with a previous study that demonstrated by photoelastic stress analysis technique a similar magnitude of stresses observed for segmented and non-segmented abutment designs for single implant condition (Ochiai et al., 2003). However, other study suggest less stress and strain in the peri-implant bone in segmented abutments (Aalaei et al., 2017). These divergences may occur due to different analysis and methodologies used in studies.

Through the use of finite element analysis, we were able to numerically determine how much stress was distributed through zirconia crowns, crowns screws, conical abutment, abutment screws, implants, cortical and medullary bone in rehabilitations using conical and UCLA abutments. However, owing to the limitations of the finite element methodology, the models used in this study did not accurately represent the actual oral conditions of humans. It is necessary to consider that there are inherent limitations to in silico simulation, mainly due to assumptions regarding masticatory forces, material properties, inclination, alignment and conditions for simulating the peri-implant tissue, such as bone which is a complex dynamic structure, and its characteristics can vary substantially between individuals. 


\section{Conclusion}

Within the limitations of the present study, it can be concluded that single implant-supported rehabilitations of mandibular first molars using external hexagon implants present better stress distribution on the crown screw and implants for the group of conical abutments compared to the UCLA abutment group. Further clinical studies are required to validate the results of the present study.

\section{References}

Aalaei, S., Rajabi Naraki, Z., Nematollahi, F., Beyabanaki, E., \& Shahrokhi Rad, A. (2017). Stress distribution pattern of screw-retained restorations with segmented vs. non-segmented abutments: A finite element analysis. J Dent Res Dent Clin Dent Prospects, 11(3):149-155. 10.15171/joddd.2017.027

Araújo, P. M., Filho, G. S., Ferreira, C. F., Magalhães Benfatti, C. A., Cagna, D. R., \& Bianchini, M. A. (2018). Mechanical Complications Related to the Retention Screws of Prefabricated Metal Abutments With Different Angulations. Implant Dent, 27(2):209-212. 10.1097/id.0000000000000742

Bordin, D., de Castro, M. B., de Carvalho, M. A., de Araujo, A. M., Cury, A. A. D. B., \& Lazari-Carvalho, P. C. (2021). Different treatment modalities using dental implants in the posterior maxilla: A finite element analysis. Braz Dent J, 32(1):34-41. 10.1590/0103-6440202103890

Brune, A., Stiesch, M., Eisenburger, M., \& Greuling, A. (2019). The effect of different occlusal contact situations on peri-implant bone stress - A contact finite element analysis of indirect axial loading. Mater Sci Eng C, 99:367-373. 10.1016/j.msec.2019.01.104

Camargos, G. de V., Sotto-Maior, B. S., Silva, W. J., Lazari, P. C., \& Del Bel Cury, A. A. (2016). Prosthetic abutment influences bone biomechanical behavior of immediately loaded implants. Braz Oral Res, 30(1):1-9. 10.1590/1807-3107BOR-2016.vol30.0065

Chun, H. J., Shin, H. S., Han, C. H., \& Lee, S. H. (2005). Influence of implant abutment type on stress distribution in bone under various loading conditions using finite element analysis. Int J Oral Maxillofac Implants, 21(2):195-202. http://www.ncbi.nlm.nih.gov/pubmed/16634489.

Coelho, P. G., Bonfante, E. A., Silva, N. R. F., Rekow, E. D., \& Thompson, V. P. (2009). Laboratory simulation of Y-TZP all-ceramic crown clinical failures. J Dent Res, 88(4):382-386. 10.1177/0022034509333968

Costa, C. M., Campos, F. O., Prassl, A. J., et al. (2014). An efficient finite element approach for modeling fibrotic clefts in the heart. IEEE Trans Biomed Eng, 61(3):900-910. 10.1109/TBME.2013.2292320

Cruz, M., Wassall, T., \& Toledo, E. M. (2010). Finite element stress analysis of dental prostheses supported by straight and angled implants. J Prosthet Dent, 104(5):346. 10.1016/s0022-3913(10)60154-0

Das Neves, F. D., Elias, G. A., Da Silva-Neto, J. P., De Medeiros Dantas, L. C., Da Mota, A. R. S., \& Neto, A. J. F. (2014). Comparison of implant- Butment interface misfits after casting and soldering procedures. J Oral Implantol, 40(2):129-135. 10.1563/AAID-JOI-D-11-00070

Di Fiore, A., Meneghello, R., Savio, G., Sivolella, S., Katsoulis, J., \& Stellini, E. (2015). In Vitro Implant Impression Accuracy Using a New Photopolymerizing SDR Splinting Material. Clin Implant Dent Relat Res, 17:E721-E729.

Dias, E. C. L., Bisognin, E. D. C., Harari, N. D., et al. (2012). Evaluation of implant-abutment microgap and bacterial leakage in five external-hex implant systems: an in vitro study. Int J Oral Maxillofac Implants, 27(2):346-351. http://www.ncbi.nlm.nih.gov/pubmed/22442774.

Dini, C., Costa, R. C., Sukotjo, C., Takoudis, C. G., Mathew, M. T., \& Barão, V. A. R. (2020). Progression of Bio-Tribocorrosion in Implant Dentistry. Front. Mech. Eng, 6:1. 10.3389/fmech.2020.00001

Estrela, C. (2018). Metodologia Científica: Ciência, Ensino, Pesquisa. Editora Artes Médicas.

Jaime, A. P. G., De Vasconcellos, D. K., Mesquita, A. M. M., Kimpara, E. T. \& Bottino, M. A. (2007). Effect of cast rectifiers on the marginal fit of UCLA abutments. J Appl Oral Sci, 15(3):169-174. 10.1590/S1678-77572007000300004

Jung, R. E., Zembic, A., Pjetursson, B. E., Zwahlen, M., \& Thoma, D. S. (2012). Systematic review of the survival rate and the incidence of biological, technical, and aesthetic complications of single crowns on implants reported in longitudinal studies with a mean follow-up of 5 years. Clin Oral Implants Res, 23(SUPPL.6):2-21. 10.1111/j.1600-0501.2012.02547.x

Lee, H., Jo, M., Sailer, I., \& Noh, G. (2021). Effects of implant diameter, implant-abutment connection type, and bone density on the biomechanical stability of implant components and bone: A finite element analysis study. J Prosthet Dent, 1-13. 10.1016/j.prosdent.2020.08.042

Lemos, C. A. A., Verri, F. R., Noritomi, P. Y., et al. (2021). Effect of bone quality and bone loss level around internal and external connection implants: A finite element analysis study. J Prosthet Dent, 125(1):137.e1-137.e10. 10.1016/j.prosdent.2020.06.029

Lima de Andrade, C., Carvalho, M., Bordin, D., da Silva, W., Del Bel Cury, A., \& Sotto-Maior, B. (2017). Biomechanical Behavior of the Dental Implant Macrodesign. Int J Oral Maxillofac Implants, 32(2):264-270. 10.11607/jomi.4797

Mezzomo, L. A., Miller, R., Triches, D., Alonso, F., \& Shinkai, R. S. A. (2014). Meta-analysis of single crowns supported by short (<10 mm) implants in the posterior region. J Clin Periodontol, 41(2):191-213. 10.1111/jcpe.12180

Ochiai, K. T., Ozawa, S., Caputo, A. A., \& Nishimura, R. D. (2003). Photoelastic stress analysis of implant-tooth connected prostheses with segmented and nonsegmented abutments. J Prosthet Dent, 89(5):495-502. 10.1016/S0022-3913(03)00167-7 
Research, Society and Development, v. 10, n. 13, e445101321461, 2021

(CC BY 4.0) | ISSN 2525-3409 | DOI: http://dx.doi.org/10.33448/rsd-v10i13.21461

Pera, F., Menini, M., Bagnasco, F., Mussano, F., Ambrogio, G., \& Pesce, P. (2021). Evaluation of internal and external hexagon connections in immediately loaded full-arch rehabilitations: A within-person randomized split-mouth controlled trial with a 3-year follow-up. Clin Implant Dent Relat Res, 23(4):562-567. $10.1111 /$ cid. 13029

Pereira A. S. et al. (2018). Metodologia da pesquisa científica. UFSM.

Quek, H. C., Tan, R. K. B., \& Nicholls, M. S. D. J. I. (2008). Load fatigue performance of four implant-abutment interface designs: Effect of torque level and implant system. J Prosthet Dent, 100(1):73. 10.1016/s0022-3913(08)60144-4

Tribst, J. P. M., Dal Piva, A. M. de O., da Silva-Concílio, L. R., Ausiello, P., \& Kalman, L. (2021). Influence of Implant-Abutment Contact Surfaces and Prosthetic Screw Tightening on the Stress Concentration, Fatigue Life and Microgap Formation: A Finite Element Analysis. Oral, 1(2):88-101. 10.3390/oral1020009

Wang, J., Lerman, G., Bittner, N., Fan, W., Lalla, E., \& Papapanou, P. N. (2020). Immediate versus delayed temporization at posterior single implant sites: A randomized controlled trial. J Clin Periodontol, 47(10):1281-1291. 10.1111/jcpe.13354 